\title{
Growth of Baltic salmon Salmo salar in the sea
}

\author{
Per-Olov Larsson
}

Swedish Salmon Research Institute, S-810 70 Alvkarleby, Sweden

\begin{abstract}
Aspects of the growth of Baltic salmon Salmo salar L are discussed. Results are mainly based on about 210000 reports of recaptured salmon out of 1.7 million tagged smolts released between 1953 and 1980 from Swedish hatcheries. Tagged and unmarked salmon seem to have equal survival and growth rates in the Baltic Sea, and so do a wild and a hatchery stock compared in one river. Results should therefore be representative for the main part of the Baltic salmon population of which $70 \%$ now are of hatchery-reared origin. During the period in question no clear trend in growth rate can be seen. Driftnet selectivity in the dominating offshore fishery for feeding fish, mainly working during the second winter in the sea when salmon reach catchable size, is shown to affect strongly size at higher ages. Comparisons with older data are therefore difficult to make. However, it is clear that growth rates of southern stocks have increased and those of the more numerous northern river stocks have decreased during the last $50 \mathrm{yr}$. This is believed to have been caused by changed environmental, rather than genetic, factors probably acting during early life in the sea. Individual variation in growth rate is large, and distributions of size at a certain age overlap between 3 age classes. Monthly mean weights of feeding salmon in the sea give a fairly good picture of growth but are influenced by gear selectivity and by spawning migrants leaving in spring being larger than average for their age class.
\end{abstract}

\section{INTRODUCTION}

Baltic salmon are a geographically isolated population of Atlantic salmon but were not separated taxonomically by Berg (1948). According to Swedish tagging experiments, about $0.04 \%$ of recaptured salmon migrated outside the Danish islands (Fig. 1). Differences between Baltic and Atlantic stocks are generally small but in some respects - for instance growth in the sea - can be sonsiderable. Formerly, data on salmon growth in the sea were mainly obtained from spawning runs (Alm, 1934; Järvi, 1948). Alm also collected data from the sea fishery and found them to be in agreement with findings from river catches. Growth rate estimates from several sets of published data from both river (Järvi, 1938, 1948) and sea catches (Kändler and Lühmann, 1957; Chrzan, 1959; Thurow, 1973) were presented by Christensen and Larsson (1979). Data from smolt tagging experiments have been reported (e.g. Carlin, 1955a, 1959, 1968; Toivonen, 1977), giving average weight per season for recaptured salmon. Carlin also included individual length and weight data against time for some experiments.

In this paper, several aspects on growth in the sea of the Swedish stocks of Baltic salmon are treated, mainly using the extensive material now at hand from about 1.7 million tagged smolts released in Swedish rivers with an average total recapture rate of $12.5 \%$

\section{MATERIALS AND METHODS}

The terminology employed in this paper follows that of Allan and Ritter (1977). Since 1951, when the extensive smolt-tagging program started, the Carlin-tag (Carlin, 1955b) has been used. Handling of tag-return data has been computerized since 1955 (Carlin, 1963, 1971)

Routine computer runs with tag-return data include calculations of average weight per season of feeding fish and spawning migrants. Spawning migrants in the computer program are defined as those fish recaptured in rivers and in coastal areas within a certain distance from the home river during the normal period for the run (May-October). Feeding fish are those caught in the offshore fishery or in coastal waters far from the home river. To give a general idea of the size at age and its possible changes within the $30 \mathrm{yr}$ of extensive smolt releases, the average weight per season for the smolt year classes 1953-1980 were included. They 
represent all taggings of hatchery-reared smolts, mainly 2 -yr-olds with 15 to $18 \mathrm{~cm}$ average total length, released in Swedish rivers to the Baltic Sea. Variation between smolt year classes in distribution of recaptures over the seasons were small and did not affect the comparability of average weights. Consequently, average date of capture also showed little variation, and season was used as time-scale unit.

The smolt year class of 1974 was selected for stockby-stock comparison of seasonal average weights. In 1974 more stocks than usual were included in the tagging program. Eight northern stocks and 2 southern ones from rivers running to the Main Basin (Fig. 1) were compared, all with 2-yr-old hatchery-reared smolts. The average weights during the 2 nd to 4 th

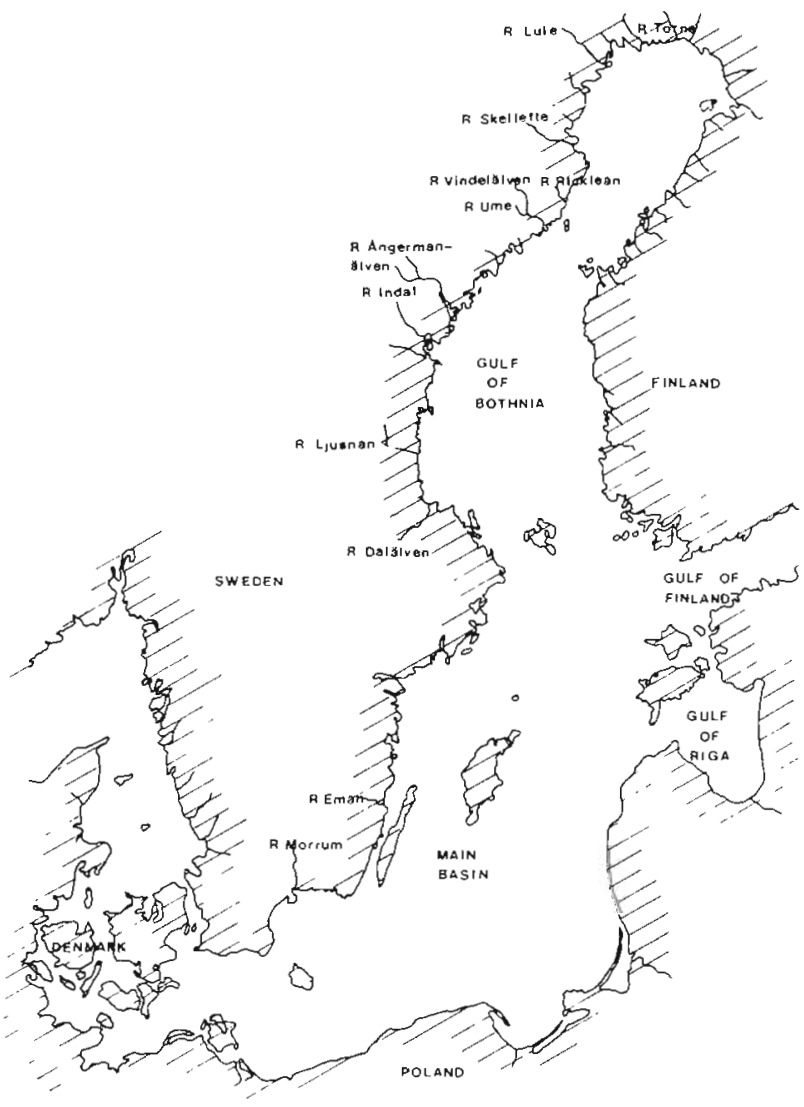

Fig. 1. Baltic Sea with locations referred to in text

winter in the sea (feeding fish) and during the 2nd $(2.1+) 3 \mathrm{rd}(2.2+)$ and 4 th $(2.3+)$ summer after release (spawning migrants) were calculated if more than 5 recaptures were reported.

The computer-calculated average seasonal weights for smolt year classes 1969-79 from River Lule, all 2 yr old hatchery-reared fish, were used to study the yearby-year variation within 1 stock. To find out if the variation between year classes is similar for the River Lule stock and the total number of Swedish stocks of
Baltic salmon investigated, the correlation between yearly deviations (\%) from the seasonal average weight for A. $1+-2$ and A. $2+-3$ feeding fish of the 2 categories was analysed. For the $A .1+-2$ age class the smolt year classes 1969-80 were included and for the A.2+-3 smolt year classes 1969-79.

All reported findings of tagged salmon are alloted to 1 mo of recapture even if no date for the catch is given. Such returns are distributed on months according to a probability system based on the monthly distribution of recaptures with date of catch reported. If no weight is given for a recaptured salmon, the average weight (of fish with reported weight) for the recapture month is recorded by computer (all weights in $\mathrm{kg} 10^{-1}$ ). Therefore it is possible to calculate fairly accurate monthly mean weights. For this study the monthly mean weights were calculated from recaptures (in the Main Basin) of feeding salmon from all the northern rivers (running to Gulf of Bothnia) released as smolts in 1969-75. Catches obtained with driftnets and longlines were treated separately, and only means based on more than 30 reported weights were included.

In the material presented so far, recaptures with estimated weights were included. The remaining material deals only with reported weights at capture. The individual weights of returning tagged spawning migrants - totaling 913 salmon - of the River Ume stock were collected for the ageclasses A.1 +, A.2 + and A.3 + from the smolt year classes of 1969-73. Known previous spawners were omitted. Since accuracy of reported weights varies considerably, the fish were divided into $1 \mathrm{~kg}$ groups. Average weights and standard errors were calculated from individual weights. The same procedure was applied on recaptures of feeding fish in the Main Basin from a randomly selected salmon sample of smolt year classes for 1969-73 with reported weight, totaling 1028 specimens of age classes A. $1+-2$, A. $2+-3$ and A. $3+$ -4 . The number of recaptures of other age classes was too small to give a representative size distribution.

In River Ume 1 salmon stock reproduces naturally in a main tributary (River Vindelälven). About 100000 hatchery-reared salmon smolts released annually have all been finclipped (adipose fin) since 1970 (Johansson, 1973) to facilitate separation in spawning migrating fish of the 2 stocks. All spawning migrants ascending the river are caught in a trap in a fish way, the only way to pass the dam at Stornorrfors, the lowest one in that river. The trap is used to collect broodstock for the hatchery and to check the wild stocks. Breeders are taken from both stocks, though only a small amount of inbreeding with the wild stock is allowed. Females weighing less than 4 to $4.5 \mathrm{~kg}$ are usually not retained.

In an investigation on salmon females and egg size (Larsson and Pickova, 1978) 43 fishes of wild and the 
same number of hatchery origin were aged. They originated from the runs in 1975 and 1976, and all were 2 or 3 seawinter fish. About the same proportions of wild and hatchery fish were omitted as breeders because they were too small. Mean weight and deviation were calculated per category (age, origin, year of catch). The size at age for A.2 + and A.3 + spawning migrants is approximately normally distributed (Fig. 7). The sample of A.2 + fish used here was not taken at random; salmon smaller than 4 to $4.5 \mathrm{~kg}$ were omitted. A few A. 3 + might also have been omitted, this is not known, but it was regarded as valid to use, for both years, a conventional t-test to analyse the possible difference in average weight of the wild and reared stock.

Aging of spawning migration salmon of 3 stocks (Lule, Skellefte, Ume rivers) was done by Larsson and Pickova (1978). Mean weights per age class and year of catch (1974-76) for those unmarked salmon were compared with the corresponding weights reported for tagged salmon returning to the river in question. All salmon were hatchery-reared, as wild salmon are distinguishable in River Ume (see above) and no natural reproduction occurs in the other 2 rivers

\section{RESULTS}

Seasonal average weights (Fig. 2) were fairly constant throughout the period, although 2 peaks can be distinguished: one around 1959, the other around 1974. The average weight of grilse is strongly affected, because most gears used are selective and only catch the larger grilse. In unselective gears the average weight normally varies between 1.2 and $1.4 \mathrm{~kg}$, both between (northern) rivers and between years. The 1979 smolt year class seems to have had unusually slow growth.

The average seasonal weights for the 10 stocks tagged in 1974 are shown in Fig. 3. Variation between the 8 northern stocks is rather low. Growth of the 2 southern stocks seems about equal, but much better than that of the northern stocks.

Fig. 4 gives average seasonal weights for 12 smolt year classes from River Lule. The covariation with the total releases of salmon in Sweden (Fig. 2) is striking. Correlation between River Lule stock and tagging program, regarding deviation from mean weight for the second winter in the sea $(A .1+-2)$, was $r=0.961$ ( $t=11.03,12 \mathrm{yr}$ ), for the third winter $(\mathrm{A} .2+-3), \mathrm{r}=$ 0.982 ( $t=15.47,11 \mathrm{yr})$.

Monthly mean weights of feeding salmon caught in Main Basin are shown in Fig. 5 as averages for smolt year classes 1969-75, separately for driftnet and longline catches. Growth seems rapid during summer (June-August) and considerably slower in winter. In spring mean weights are affected by salmon being larger during the spawning migration than the average for the age class. The decline in mean weight for fish remaining in the sea is more or less pronounced (Fig. 6).

The distributions of weight classes per age class of spawning migrants and feeding fish are given in Fig. 7 and 8 respectively. In the older age groups a few repeat spawners may appear, normally having a lower weight than the average for that age class. However, the proportion of repeat spawners is small. In Danish offshore catches Christensen and Larsson (1979) esti-

Fig. 2. Seasonal mean weights of Baltic salmon recaptured as spawning migrants (dots) and feeding fish (dashes) for hatcheryreared smolts released $1953-80$

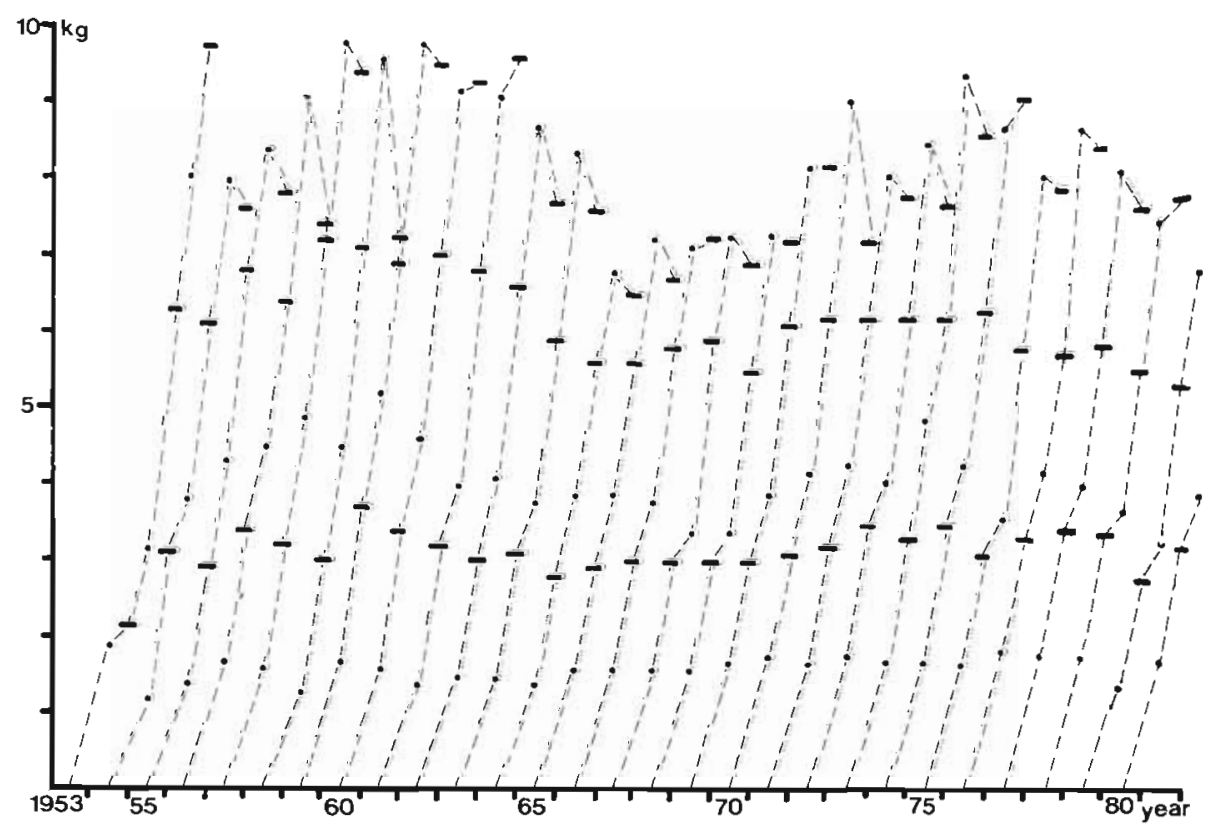




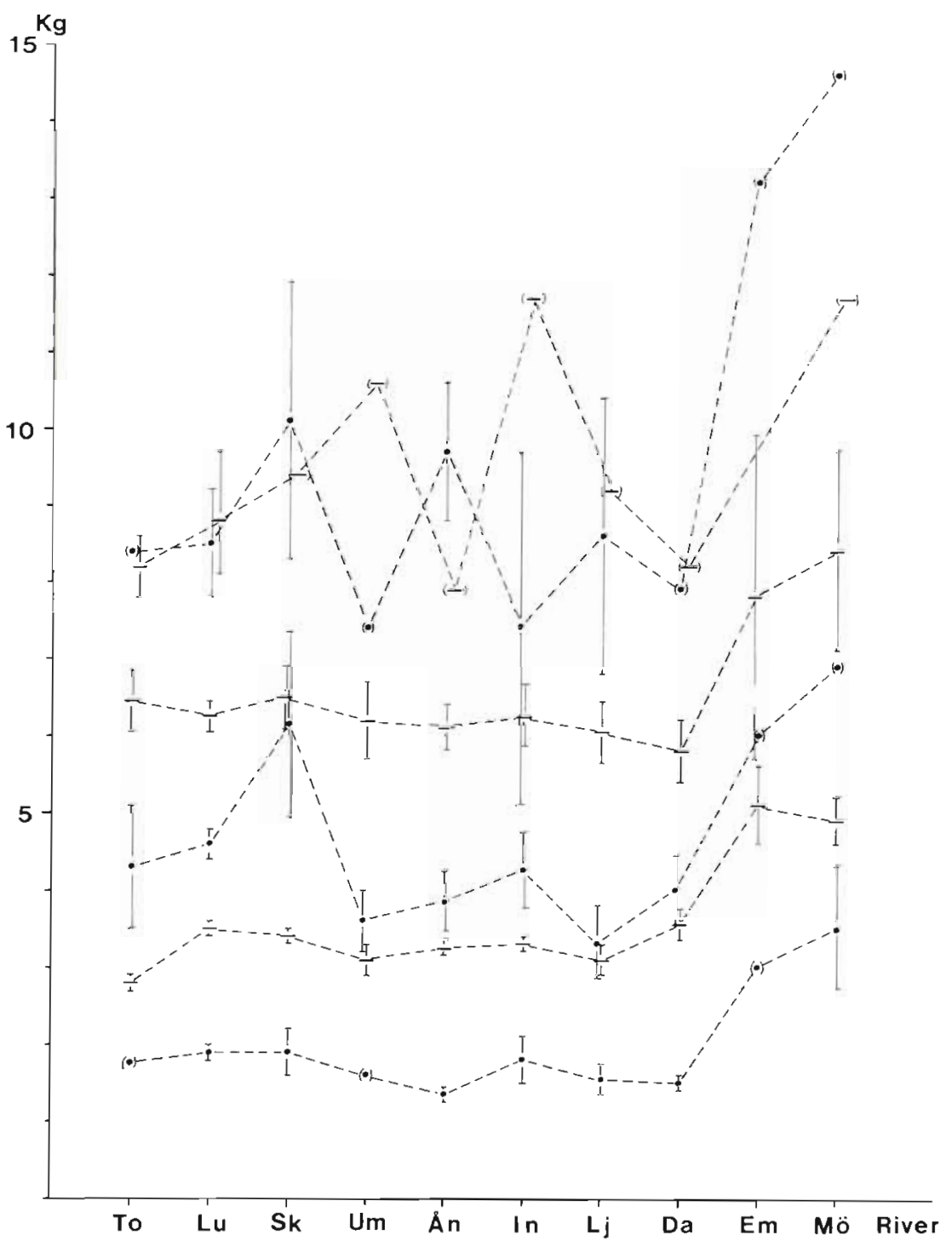

Fig. 3. Mean weight per season of recaptured salmon tagged as hatchery-reared smolts 1974 in rivers Torne (To), Lule (Lu), Skellefte (Sk), Ume (Um), Ångermanälven (Ån), Indal (In), Ljusnan (Lj), Dalälven (Da), Emån (Em) and Mörrumsån (Mö). Spawning migrants after 1 to 3 sea winters (dots) and feeding salmon during 2 nd to 4 th sea winter (dashes). In brackets: values based on less than 10 reports

mated the percentage to be $1.3 \%$ for the season $1974 / 75$, divided into $0.6 \%$ grilse and $0.7 \%$ salmon spawners. In the material presented in Fig. 8 this means, for example, that 2 or 3 of the 428 salmon with age A.2 + -3 might be a previous grilse. Individual variation is considerable, e.g. $0.9 \mathrm{~kg}$ to $8.2 \mathrm{~kg}$ for $\mathrm{A} .2+$ spawning migrants (average $4.2 \mathrm{~kg}$ ), and $2.2 \mathrm{~kg}$ to $13.1 \mathrm{~kg}$ for 1 yr older fish (average 8.1). Among feeding fish, the variation is not quite as large for the two-seawinter fish ( 1.3 to $5.5 \mathrm{~kg}$, average $3.1 \mathrm{~kg}$ ) but $1.9 \mathrm{~kg}$ to $13.2 \mathrm{~kg}$ in the third winter $(\mathrm{A} .2+-\mathrm{A} .3$, average $6.3 \mathrm{~kg})$.

Table 1 shows individual weights per age class, origin and year of catch of salmon caught during the spawning migration and kept for breeding in River Ume. There seems to be no covariation in growth between wild and hatchery-reared stocks. The only statistically significant difference between average weights is in favour of hatchery-reared fish $(\mathrm{A} .3+)$ in $1976(t=2.498,0.01<p<0.02)$. Considering the small samples and the large variation (Fig. 7 and 8 ) it is doubtful if the t-test is really applicable, and it seems safe only to conclude that there are no indications of a considerably faster growth for either category.

Seasonal average weights of tagged and unmarked A. 2 + and A. 3 + spawning migrators in 3 rivers are given in Fig. 9 and Table 2. There appears to be a difference in favour of unmarked fish of age A.2+ in most cases. This, however, depends on agedunmarked salmon selected for stripping, several small specimens having been rejected (see above). This is not applicable to the same extent to the River Lule stock in 1976 and to the A.3 + fish, and no such differences can be observed in those cases. 


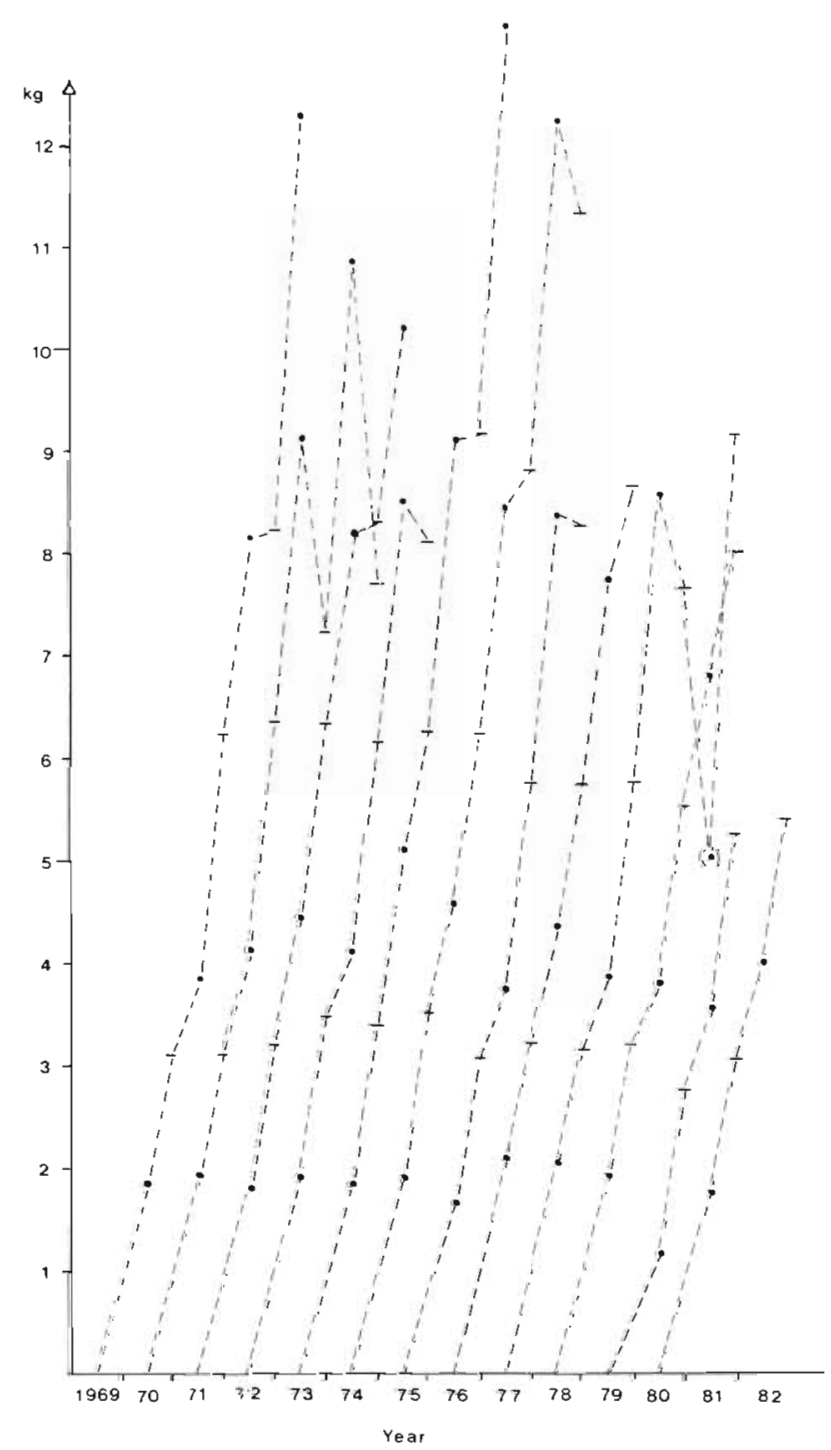

Fig. 4. Mean weight per season of salmon tagged as smolts in River Lule 1969-80. Spawning migrants (dots) and feeding fish (dashes). In brackets: values based on less than 10 reports

\section{DISCUSSION}

Of the Baltic salmon population, with a present yearly smolt output of about 4 million artificial smolt units (Anon., 1980), about $85 \%$ emanate from rivers flowing to the Gulf of Bothnia. This figure is based on national contributions reported by the Baltic Salmon Assessment Working Group (Anon., 1982) and on the consideration that only about 50000 of the smolts produced in Swedish rivers come from affluents to the Main Basin. Generally, northern stocks have poor firstyear growth in the sea, compared to e.g. Norwegian stocks in rivers at the same latitude (Hansen, 1983; see also Table 3). Later, growth improves and mean weights of spawning migrants with 3 sea years are comparable with those of the Norwegian stocks. The

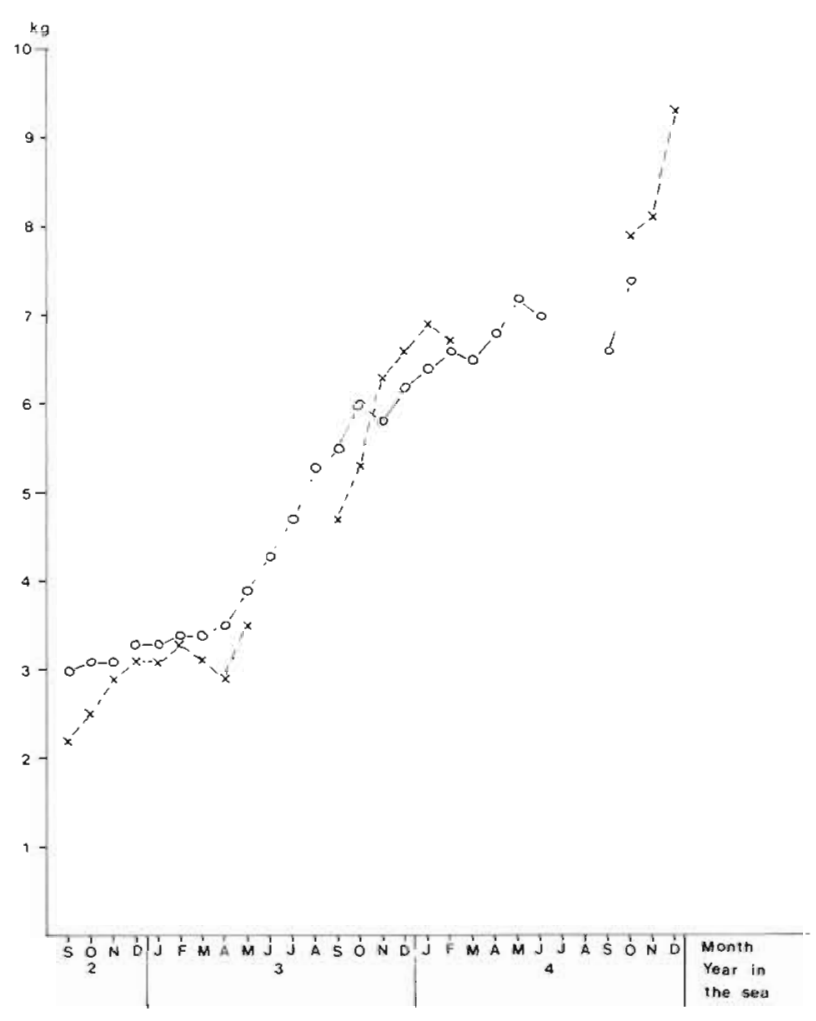

Fig. 5. Monthly mean weights of feeding salmon tagged as smolts and caught on driftnets $(0-0)$ and long lines $(x-x)$ during their second, third and fourth year in the Baltic Main Basin. Smolt year classes 1969-75

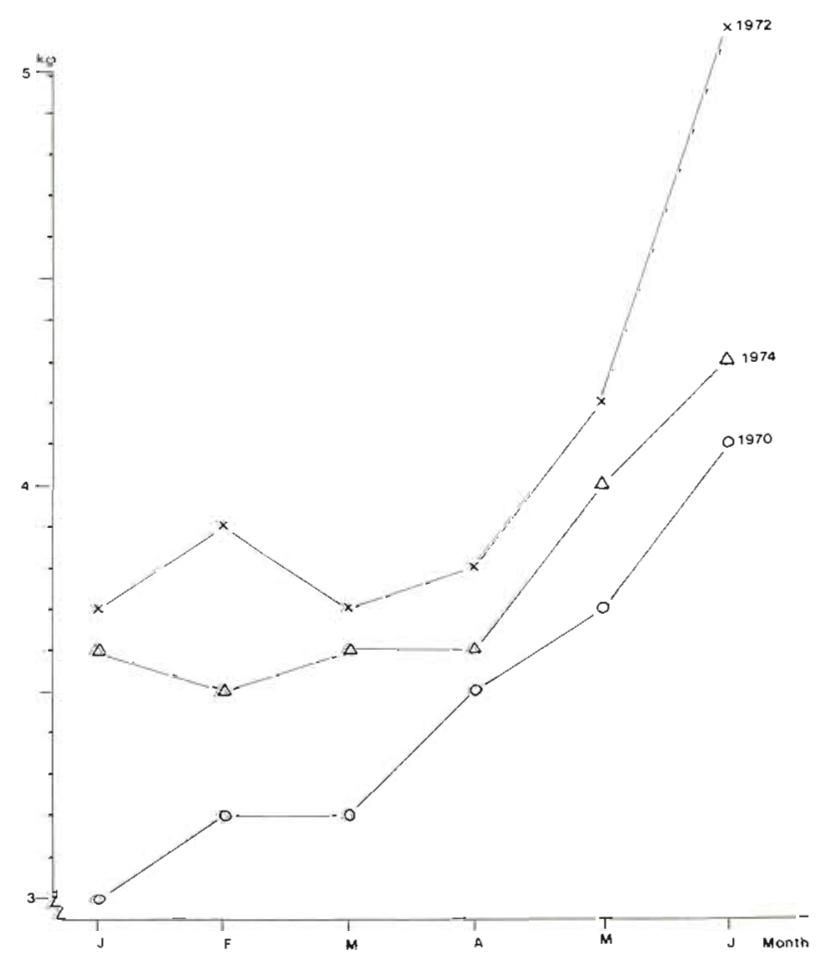

Fig. 6. Monthly mean weight of recaptured feeding salmon in January-June for the 2nd winter in the sea. Smolt year classes $1970,1972,1974$ 


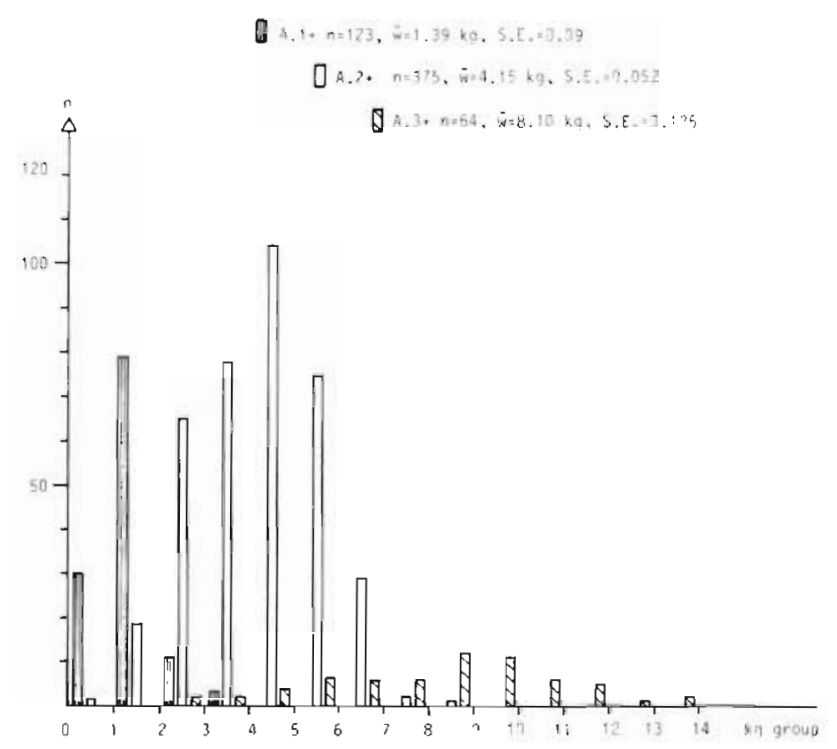

Fig. 7. Distribution of weight groups of salmon tagged as smolts and returning to River Ume after $1(\mathrm{~A} .1+), 2(\mathrm{~A} .2+)$ and $3(\mathrm{~A} .3+)$ winters in the sea

southern Baltic stocks exhibit a growth rate fully comparable to Atlantic stocks.

The potential growth capacity of Baltic salmon is, however, difficult to estimate nowadays because of the intensive offshore fishery for feeding fish. Thurow (1968) estimated a fishing mortality of $37 \%$ for A.1 + fish during their second winter in the sea when the fishing season was mainly from September to May. The corresponding value for A.2 + salmon was $48 \%$. Larsson (1982) found as an average for the 1970's a seasonal fishing mortality of $48 \%$ for A.1 +, and of $62 \%$ for A. 2 + salmon. He also found it necessary to add a non-catch fishing mortality (Ricker, 1976; Ritter et al., 1979; and others) possibly as high as $5 \%$

When the offshore fishery for feeding fish started to expand around 1950, longlines were the most important gear. Later, nets were used to a greater extent and these have been the dominating gear from the mid1960's (Thurow, 1973). In the 1970's, driftnets were responsible for about $80 \%$ of the catches and significant longline catches were normally obtained only in November and December (Christensen and Larsson, 1979).

Longline catches are presumed to reflect the composition of the stock present in the exploited area (Thurow, 1964), while driftnets have been shown to fish highly selectively. The $50 \%$-retention length of salmon in nets with a stretched mesh size of $160 \mathrm{~mm}$ (close to the minimum mesh size allowed in the Baltic since 1967 ) is estimated to range from 61 to $78 \mathrm{~cm}$ for the lower iimit to 95 to 107 for the upper limit (Christensen, unpubl.; Thurow, 1966, 1969, 1972). Applying a condition factor of 1.1 (Thurow, 1966) the corresponding weight intervals will be 2.5 to $5.2 \mathrm{~kg}$ and 9.4 to $13.5 \mathrm{~kg}$. The wide range is, however, explained by the variability of the condition factor during the season (Christensen, 1961).

The monthly mean weights of feeding salmon in the offshore fishery (Fig. 5) clearly show the difference between longlines and driftnets. Throughout the second winter season and in the beginning of the third sea winter the mean weights of salmon in the net catches are higher than in the line catches, which are presumed to be close to the true size of the age class. According to recapture data of tagged salmon, around $50 \%$ of the total number of recaptures were feeding

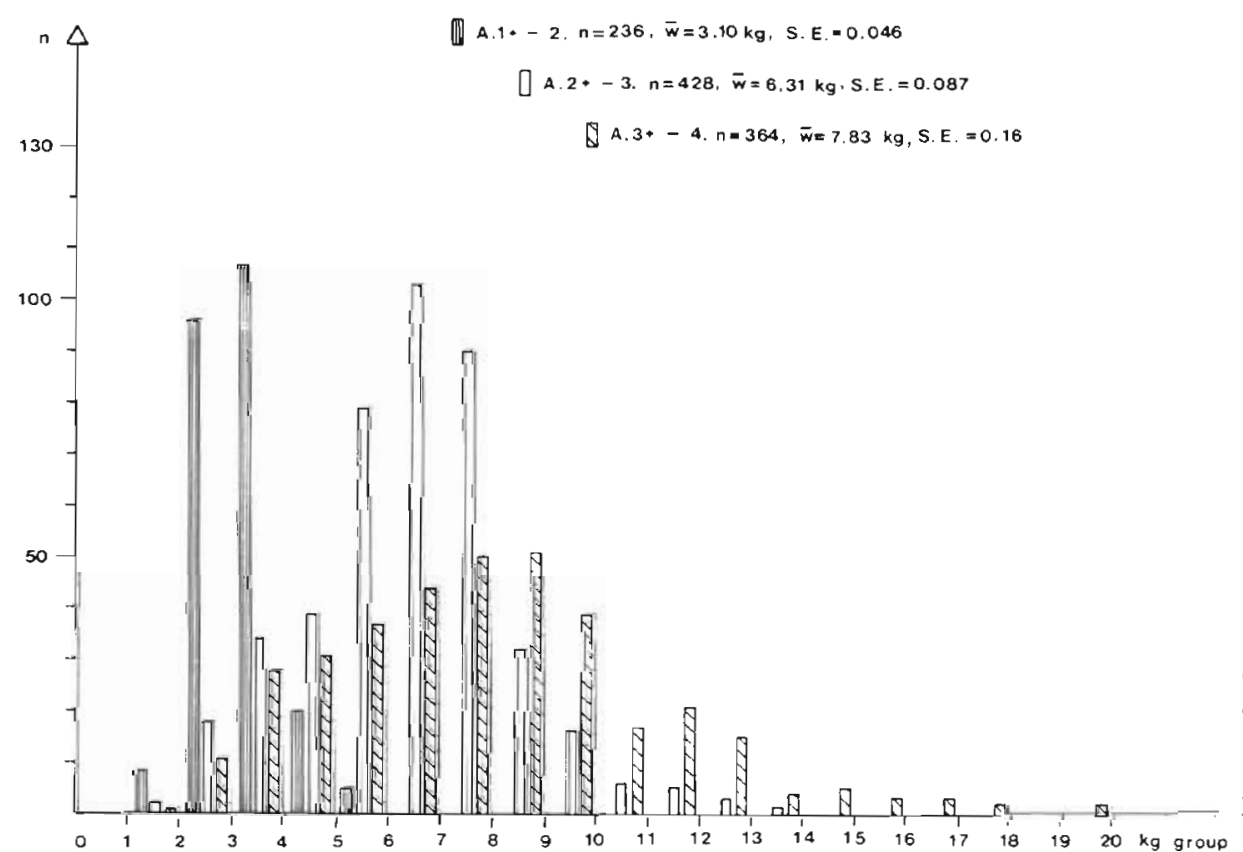

Fig. 8. Distribution of weight groups of salmon tagged as smolts and recaptured during their 2 nd $($ A. $1+-2)$, 3rd (A.2 +-3$)$ and 4 th (A.3+ - 4) winter in the sea. Number of fish per age class is not a natural distribution 
Table 1. Weight $(\mathrm{kg})$ of salmon collected for broodstock in River Ume and of spawning migrants of the wild stock reproducing in the river

\begin{tabular}{|c|c|c|c|c|c|c|c|c|}
\hline \multirow{3}{*}{$\begin{array}{l}\text { Year } \\
\text { Origin } \\
\text { Age }\end{array}$} & \multicolumn{4}{|c|}{1975} & \multicolumn{4}{|c|}{1976} \\
\hline & \multicolumn{2}{|c|}{ Wild } & \multicolumn{2}{|c|}{ Reared } & \multicolumn{2}{|c|}{ Wild } & \multicolumn{2}{|c|}{ Reared } \\
\hline & A. $2+$ & A. $3+$ & A. $2+$ & A. $3+$ & A. $2+$ & A. $3+$ & A. $2+$ & A. $3+$ \\
\hline & 4.9 & 6.0 & 4.6 & 5.0 & 4.0 & 5.5 & 4.2 & 6.0 \\
\hline & 4.9 & 7.7 & 5.3 & 6.6 & 4.2 & 6.1 & 5.6 & 6.2 \\
\hline & 5.2 & 8.0 & 5.3 & 6.7 & 4.2 & 6.9 & 6.3 & 7.2 \\
\hline & 5.5 & 8.5 & 5.4 & 7.1 & 4.5 & 7.0 & & 7.7 \\
\hline & 5.5 & 8.7 & 5.5 & 7.5 & 4.6 & 7.0 & & 8.5 \\
\hline & 5.6 & 9.0 & 5.7 & 7.8 & 5.2 & 7.1 & & 8.5 \\
\hline & 5.7 & 9.3 & 5.9 & 8.0 & 5.3 & 7.2 & & 8.5 \\
\hline & 7.3 & 10.0 & 6.0 & 8.3 & 6.1 & 7.3 & & 8.6 \\
\hline & & & 6.3 & 8.5 & 6.3 & 7.5 & & 9.0 \\
\hline & & & 6.4 & 9.0 & 7.5 & 7.5 & & 9.0 \\
\hline & & & 7.5 & 9.4 & & 7.8 & & 9.3 \\
\hline & & & 7.6 & 10.4 & & 8.1 & & 9.5 \\
\hline & & & & & & 8.2 & & 9.7 \\
\hline & & & & & & 8.4 & & 10.0 \\
\hline & & & & & & 9.0 & & 10.2 \\
\hline & & & & & & 9.1 & & 10.2 \\
\hline & & & & & & 9.3 & & \\
\hline Number & 8 & 8 & 12 & 12 & 10 & 17 & 3 & 16 \\
\hline Mean weight & 5.58 & 8.40 & 5.96 & 7.86 & 5.19 & 7.59 & 5.37 & 8.63 \\
\hline Standard error & 0.27 & 0.43 & 0.26 & 0.41 & 0.36 & 0.25 & 0.62 & 0.32 \\
\hline
\end{tabular}
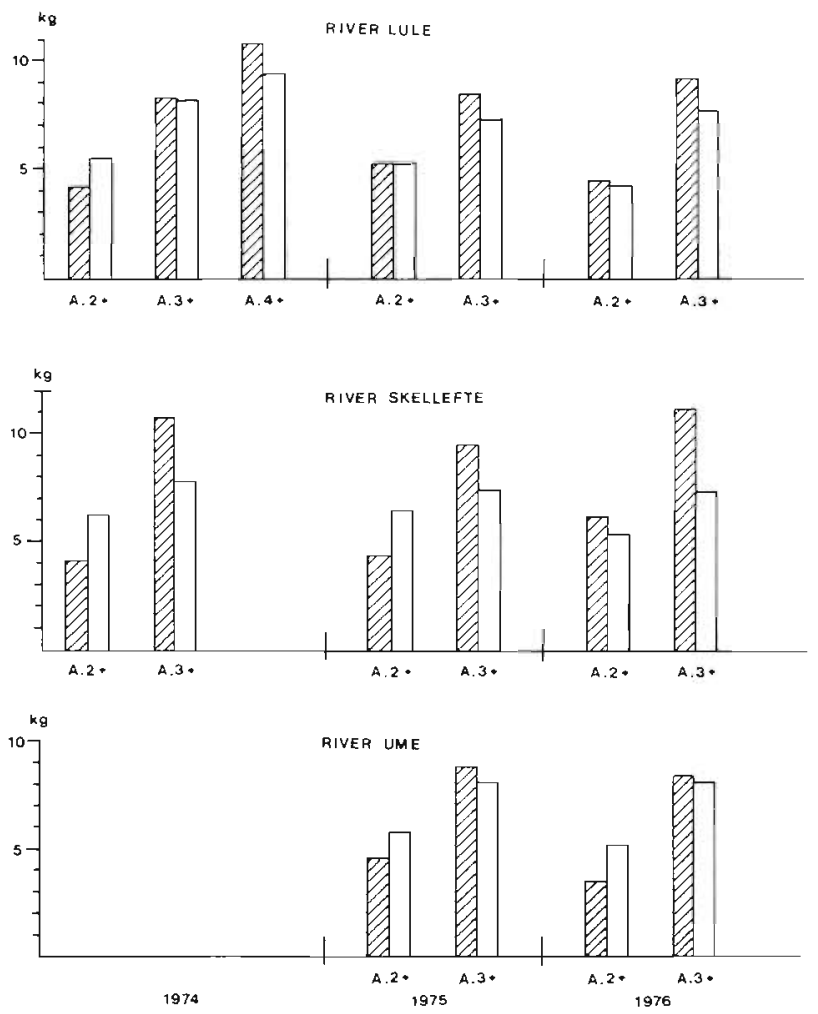

Fig. 9. Mean weight per age class of spawning migrating salmon in River Lule, River Skellefte and River Ume, 1974-1976. Tag returns (shaded bars) and unmarked fish (open bars) aged from scales fish during their second sea winter, which corresponds to about $70 \%$ of all feeding fish (Larsson, 1982). This would mean that the selectivity of the driftnets must have a considerable effect on the size of adult Baltic salmon of all ages, though the few - but fastest growing - fish caught already during their first sea winter probably do not affect the average weight of the grilse (A.1 + spawners) very much. From Fig. 7 and 8 also appears that the variation in weight is less for salmon recaptured during the second winter than those returning to the rivers the following season, in spite of the fact that the former contain recaptures with gear other than driftnets, and from several stocks.

The size at age values for salmon from about 1950 to date can thus not be compared with earlier dates, e.g. those published by Alm (1934) and Järvi (1938, 1948). It is also impossible to judge, whether the decline in catch rate from about 1940, reported by Järvi (1948) and analysed by Lindroth $(1964,1965)$, is a temporary phenomenon or not. In the material presented in Fig. 2 the declining weights from around 1960 might be an effect of the increasing importance of driftnets in the offshore fishery. From the middle of the sixties and onwards, however, the size at age should be an index of the apparent growth rate, as the driftnet/longline ratio has been fairly constant since then according to tag returns. The average weight for feeding fish during the third sea winter is probably giving the best estimate as the selectivity of the driftnets seems to be less 
Table 2. Mean weight $(\bar{w})$, number (n) and $95 \%$ confidence limits (c. 1.) of the material presented in Fig. 9

\begin{tabular}{|c|c|c|c|c|c|c|c|c|c|}
\hline $\begin{array}{l}\text { Year and } \\
\text { age class }\end{array}$ & $\begin{array}{l}\bar{w} \\
\mathrm{~kg}\end{array}$ & $\begin{array}{l}\text { ver } L u \\
n\end{array}$ & $\begin{array}{c}\text { c. } 1 \\
\pm\end{array}$ & $\begin{array}{l}\overline{\mathrm{w}} \\
\mathrm{kg}\end{array}$ & $\begin{array}{c}\text { Ske } \\
\text { n }\end{array}$ & $\begin{array}{c}\text { C. } 1 \\
\pm\end{array}$ & $\begin{array}{l}\bar{w} \\
\mathrm{~kg}\end{array}$ & ${ }_{n}^{e r U}$ & $\begin{array}{c}\text { c. } 1 \\
\pm\end{array}$ \\
\hline \multicolumn{10}{|l|}{$\begin{array}{l}\text { Tagged } \\
1974\end{array}$} \\
\hline A. $2+$ & 4.1 & 196 & 0.1 & 4.2 & 49 & 0.4 & & & \\
\hline A. $3+$ & 8.2 & 92 & 0.7 & 10.8 & 21 & 0.6 & & & \\
\hline $\begin{array}{l}\text { A. } 4+ \\
1975\end{array}$ & 10.9 & 17 & 2.9 & & & & & & \\
\hline A. $2+$ & 5.2 & 158 & 0.1 & 4.3 & 22 & 0.5 & 4.6 & 17 & 0.6 \\
\hline $\begin{array}{l}\text { A. } 3+ \\
1976\end{array}$ & 8.5 & 34 & 0.7 & 10.1 & 19 & 0.6 & 8.9 & 16 & 1.0 \\
\hline A. $2+$ & 4.6 & 270 & 0.1 & 6.2 & 13 & 0.8 & 3.6 & 25 & 0.4 \\
\hline A. $3+$ & 9.1 & 43 & 0.8 & 11.3 & 6 & 1.9 & 8.4 & 7 & 2.0 \\
\hline \multicolumn{10}{|c|}{$\begin{array}{l}\text { Not tagged } \\
1974\end{array}$} \\
\hline $4.2+$ & 5.6 & 24 & 0.5 & 6.2 & 47 & 0.4 & & & \\
\hline A. $3+$ & 8.2 & 40 & 0.6 & 7.9 & 17 & 1.2 & & & \\
\hline $\begin{array}{l}\text { A.4t } \\
1975\end{array}$ & 9.4 & 8 & 1.5 & & & & & & \\
\hline A. $2+$ & 5.1 & 91 & 0.3 & 6.5 & 12 & 1.2 & 6.0 & 12 & 0.6 \\
\hline $\begin{array}{l}\text { A. } 3+ \\
1976\end{array}$ & 7.4 & 18 & 0.6 & 7.6 & 23 & 0.6 & 7.9 & 12. & 0.9 \\
\hline A. $2+$ & 4.1 & 55 & 0.3 & 5.6 & 39 & 0.5 & 5.4 & 3 & 2.0 \\
\hline A. $3+$ & 7.8 & 50 & 0.7 & 7.5 & 11 & 1.2 & 8.6 & 16 & 0.7 \\
\hline
\end{tabular}

pronounced with that size of salmon (see above). The only obvious change during that period is a general decline starting with the smolt year class 1975. This decline coincides with an increase in the cod population in the Bothnian Sea culminating in 1978-79 according to Aro and Sjoblom (1981). The increase was estimated to be about 9-fold from 1974 to 1978 which might well have a competitive effect on the growth of the postsmolts considering the oligotrophic feature of this sea (e.g. Sandström and Sörlin, 1981). It is interesting to note that the decline in growth rate in the early fourties reported by Järvi (1948) also coincided with a cod invasion in the Bothnian Bay of the same magnitude (Hessle, 1949). Olofsson (1932) reported on reduced growth rates during specific years, e.g. 1931, but in his opinion these were attributable to a higher proportion than normal of the salmon staying in the Gulf of Bothnia where the productivity is lower and the growth season shorter than in the Main Basin.

The variation in weight at age between the salmon stocks from the northern rivers - Torne to Dalälven - is rather small, but the 2 southern stocks - Emán and Mörrum - obviously grow considerably faster. This is consistent with results from taggings of smolts of other year classes. Salmon of the southern stocks often reach catchable size during their 1 st sea winter, up to $30 \%$ of the total number of recaptured feeding fish compared with, at most, $1 \%$ of the northern stocks. The driftnet selectivity is again recognizable, causing the size dif- ference between the southern and the northern stocks proportionally to be smaller during the 3rd than the 2nd sea winter.

The weights of salmon from different river stocks essentially the same as in Fig. 3 - reported by Alm (1934) show an astonishing similarity for all stocks and all age classes. His data on feeding fish are not easily compared with the present data but with the spawning migrants it is noted that the grilse $(A .1+$ ) nowadays seem to be larger in River Mörrum, $3.5 \mathrm{~kg}$ against $2.4 \mathrm{~kg}$ (29 fishes) reported by Alm, while grilse in the northern rivers were also about $2.4 \mathrm{~kg}$ in the 1920's and now they are 1.4 to $1.9 \mathrm{~kg}$. For A.2 + salmon there are no indications of a change in average size in River Morrum but in the northern rivers there is a decline from 80 to $85 \mathrm{~cm}(6$ to $7 \mathrm{~kg}$ ) to 70 to $75 \mathrm{~cm}$ (4 to $5 \mathrm{~kg}$ ).

Alm (1934) found the growth differences between river stocks remarkably small but consistent through the years, thereby indicating a genetic origin of the variation in growth rate between the stocks. Naevdal et al. (1979) studied variation in length at age for groups of Atlantic salmon reared together in net pens in the sea. Variations were claimed to be largest between stocks, but there were also clear differences between sib groups from the same strain. Refstie (1979) reported similar investigations with more than 40 stocks; large variations in growth rate also were found, but these variations were as large between families within 1 stock as between stocks. Further evidence of 
Table 3. Average weight $(\mathrm{kg})$ of recaptured grilse from 8 different stocks (Hansen, pers. comm.)

\begin{tabular}{|c|c|c|c|c|c|c|c|c|}
\hline \multirow[b]{2}{*}{ River stock } & \multicolumn{4}{|c|}{ Salmon stocks } & \multicolumn{4}{|c|}{ Grilse stocks } \\
\hline & Alta & Suldal & Åröy & Eira & $\begin{array}{c}\text { Sandviks } \\
\text { elva }\end{array}$ & Figgjo & Imsa & Lone \\
\hline Number & 32 & 17 & 23 & 23 & 24 & 37 & 39 & 33 \\
\hline Mean weight & 3.4 & 2.9 & 3.4 & 3.2 & 2.7 & 2.6 & 2.8 & 1.8 \\
\hline Range & $1.5-4.7$ & $1.8-4.2$ & $2.0-5.6$ & $2.0-4.9$ & $2.0-3.5$ & $1.8-4.0$ & $1.2-4.9$ & $0.6-3.1$ \\
\hline
\end{tabular}

genetic variation has been obtained by Thorpe and Morgan $(1978,1980)$ in investigations of reared parr of Scottish salmon. Lindroth (1972) estimated the heritability of early growth (1-summer parr) in salmon to above $60 \%$. According to Rasmuson (1983) the high value may be due to the fact that heritability in this case included non-additive genetic variance, and to the very uniform culturing environment. Ryman (1972) analysed the weight of Baltic salmon recaptured during their 2nd and 3rd winters in the sea and estimated the value of heritability for recapture weight to be $22 \%$; this, however, was considered on overestimate.

At the Ims hatchery, near Stavanger, Norway, salmon of 8 different stocks were reared to 2 -yr-old smolts, all released together in the mouth of the river Imsa, some 1000 stock $^{-1}$ Carlin-tagged. The stocks were from all parts of Norway, 4 of them regarded as fast growing stocks mainly producing multi sea-winter salmon and the other 4 as grilse stocks. Only grilse have been checked so far (returning in 1982) with the following results (Table 3; Hansen, pers. comm.).

The tagged fish of the R. Mörrum and R. Emån stock in 1974 were large 2-yr-old hatchery-reared smolt, $23 \mathrm{~cm}$ average length. In both rivers wild smolts have been tagged in the 1960's (Lindroth, 1977) and in R. Mörrum also 1-yr-old hatchery-reared smolts have been released with an average length of 12 to $13 \mathrm{~cm}$, which is equal to the wild smolts (Larsson et el., 1979). In all these cases the size at age was almost the same as for the 2-yr-old hatchery fish, and much higher than for the northern stocks. The single remaining salmon stock in Poland, spawning naturally in R. Drawa, exhibits a growth rate similar to, or even superior to the 2 southern Swedish stocks (Chrzan, 1969; Chelkowski and Chelkowska, 1979).

Melnikova (1980) reported for River Neva (discharging into the Gulf of Finland) salmon sizes at age comparable to the 3 southern stocks during the 1970 's and slightly lower during 1929, 1934 and 1936. Although this is partly in conflict with the results of Alm (1934), compared to the results presented here, it seems clear that currently there is a significant difference in growth rate between salmon stocks from rivers discharging into the Main Basin and stocks from the Gulf of Bothnia rivers, and that the difference is caused by envirommental factors that have changed during the last 50 yr.

Thurow (1968) suggested the growth rate of adult salmon to be largely determined by the amount of food available for postsmolts during the first few months in the sea (see also Svärdson, 1955). This would mean that food production was equal over the whole Baltic area in the 1920's and in the last decades has improved in the Main Basin and possibly declined in the Gulf of Bothnia. The general eutrophication of the Baltic Sea, especially affecting the Main Basin, could be an explanation, but it should be pointed out that postsmolts during early sea residence consume mainly aerial insects in the Gulf of Bothnia (Lindroth, 1961; Anon., 1983), while in the Main Basin small fish and nectobenthic crustaceans are also important (e.g. Eichelbaum, 1916; Henking, 1931; Mitans, 1970).

From cage experiments with wild and reared smolts in the Gulf of Bothnia Osterdahl (1964) concluded that shortage of food may reduce growth of postsmolts. The growth rate variation between smolt year classes is similar for all Gulf of Bothnia stocks, as exemplified by the R. Lule stock in Fig. 4 (compared to Fig. 2), which also indicates a common mechanism acting in the sea, probably in the early postsmolt stage

Growth estimates based on monthly mean weights of feeding salmon (Fig. 5) do not produce the natural pattern. They only concern the remaining part of the stock apparently exhibiting a slower growth than the maturing fish leaving for spawning migration in the spring (Alm, 1959). Time and duration of the start of migration as well as the proportion of salmon leaving vary strongly between years, causing the varying effect on the monthly mean weights seen in Fig. 6. In his investigations on German catches of feeding salmon Thurow (1973) also found a decline in mean weight in the spring catches.

Growth as described by monthly mean length would give a smoother curve, as the smaller increase in weight in the winters is parallelled by a decline in condition (Christensen, 1961). Still, the pattern remains with faster growth in the summer, contrary to Alm's (1934) findings. His figures on summer growth, however, were probably based on a mixture of feeding fish and spawning migrating salmon. Growth calcu- 
lated from catches of feeding fish show the same pattern as reported here (e.g. Christensen, 1961; Thurow, 1966).

Individual variation in growth rate is reported by several authors in the form of size distribution of salmon of certain ages (e.g. Alm, 1934; Thurow, 1966, 1968, 1973; Christensen, 1976; Christensen and Larsson, 1979). In cases when all salmon were aged (from scales) the size distribution per age class was similar to that presented here, but Alm (1934) obtained a slightly narrower distribution (feeding fish) and with no overlapping between 1 st and 2 nd-winter fish. As pointed out by Thurow (1973), and obvious from the tag return data (Fig. 7 and 8), there is considerable overlap in the size distribution of different age classes. However, considering the difficulties in interpreting salmon scales (Svärdson, 1957; Alm, 1959; Carlin, 1960; Pippy and Reddin, 1982), allthough they are regarded as fairly easy to read (Järvi and Menzies, 1936), results based totally on ageing of salmon from scales should be regarded with some caution.

Comparisons of wild and reared salmon are always difficult and in many aspects impossible. Osterdahl (1969) and Toivonen (1977) compared wild smolts caught in traps close to the mouth of 2 small rivers at the Gulf of Bothnia with hatchery-reared smolts. In both cases the reared fish were 2-yr-old (more or less smoltified), from different river stocks, reared in hatcheries at other rivers and transported to and released at the site of the traps. Osterdahl could obtain reared fish with the same average size as the wild smolts (about $155 \mathrm{~mm}$ ) but in the Finnish experiment the reared fish were about $15 \mathrm{~mm}$ larger. Under these circumstances growth and survival were better for the wild salmon. As mentioned, results from $\mathrm{R}$. Mörum show another pattern with equal survival and growth for wild and $1 \mathrm{yr}$ reared smolts and much better survival and also faster growth for 2-yr-old reared smolts. Similar results were obtained in R. Emån and also R. Atran at the Swedish west coast (Larsson et al., 1979).

In the comparison presented here the reared smolts were 2-yr-old and rather small $(169,159,158 \mathrm{~mm}$ average length for the smolt year classes in question) while the size of the wild smolts was unknown but probably similar to that of the nearby R. Rickleån (152 to $161 \mathrm{~mm}$, variation in mean length 1961-1964, Osterdahl, 1964). The inbreeding of the wild stock with the reared stock was too small during the 1970 's to influence the results obtained. In other respects, e.g. time of ascending the river, there were clear differences (Johansson, 1973). The reason for the growth being equal for wild and reared fish, contrary to the findings of Osterdahl and Toivonen, could be that the reared smolts were directly released from the hatchery to the home river to which they might still be well adapted or that they were better smoltified. In Sweden the value of a reared salmon smolt is, e.g. when calculating compensation numbers to be released, regarded as half that of a wild smolt, considering both survival and growth. In the author's opinion this is not generally true as there exist several examples of other relations in both respects as indicated previously. Reared smolts of high quality, size being an important factor, obviously can be equally or even better fit for survival and growth after release than are wild smolts, and likely it is possible to raise the average quality of the reared fish to that level.

In checking the results of releases of reared fish by marking a representative sample of them it is important to know to what extent the marked fish are affected by the tag and/or the marking procedure. Isaksson and Bergman (1978) compared Carlin-tagged and micro-tagged salmon returning to Icelandic waters and found a higher sea mortality (and tag losses) as well as a lower growth rate in the Carlin-tagged fish. Saunders and Allen (1967) reported similarly that Carlin tags and fin clips affected the length at return of grilse of Canadian Atlantic salmon. Hansen (1981) investigated the effect of Carlin-tagging and finclipping on wild smolts in River Imsa, Norway, where the whole smolt run is checked in a trap. In 1 yr about one third of the run was marked in either way or released from the trap without handling. From the grilse run it appeared that the unhandled fish had about twice the survival of the marked fish. The tag itself seemed however to have little effect as there was practically no difference between the Carlin-tagged and the finclipped fish in number returning. Hansen did not report the average sizes for the 3 groups. In the Baltic Sea, conditions are much different from those in the Atlantic Ocean. The low salinity should not be harmful to salmon with possible wounds from tags and no or very little growth - of algae and settling animals (mussels and others) - on the tags can be expected. Larsson (unpubl.) attempted to calculate mortality associated with tags and tag losses, by comparing the proportion of tagged smolts released in a river without natural smolt production with the proportion of tagged adults caught in the following years in the fully controlled fishery for breeding fish. In River Angermanälven 15600 smolts were tagged in 3 yr, comprising $1.46 \%$ of the total number released. In the subsequent years 1880 salmon of the relevant age classes were caught, 48 to them tagged $(2.55 \%)$. In River Lule $33(5.08 \%)$ tagged spawning migrants were caught from 1 smolt year class of which $4.94 \%$ were tagged. The number of returns was in both cases small, as an effect of the intensive offshore fishery, but surprisingly tagged fish seemed to show better survival than untagged fish. The only explanation is that smolts smaller than $13 \mathrm{~cm}$ 
are normally not tagged - they usually give very poor results - while 1 to $5 \%$ of the total number of fish were below that size and with almost no survival they might bias the results. The conclusion is that differences in sea mortality, if any, must be small between tagged and untagged Baltic salmon smolts.

In the similar comparison made here regarding growth, the figures on average weight are not fully comparable. As already pointed out the breeders are normally selected from the catch and the 'minimum size' applied varies according to the size of the run. From Fig. 7 it appears however that even a 'minimum size' of $4 \mathrm{~kg}$ would affect the average weight of both the A.2+ and (slightly) the A.3+ fish.

The scales for ageing were taken in connection with stripping, which means it was impossible to get scales, useful for ageing, from males. Thus only females are included in the mean weights of unmarked fish. Christensen (in Christensen and Larsson, 1979) reports A. $1+$ males feeding in the Main Basin to be $4.5 \%$ heavier than the females on average, while the difference was smaller for A.2 + fish $(3.8 \%)$. Contrary to this, Alm (1934) found the difference to be only $1.7 \%$ for A. 2 + spawning migrators but $6.8 \%$ for A. $3+$ fish. As the tagged fish consisted of about the same proportion of females and males, their average weights can be estimated to be about $2.5 \%$ higher than for the females alone.

The weights of the unmarked salmon were all recorded immediately before stripping in late October, while the recaptures of tagged fish were spread over the run, from early July up to and including stripping. Most of the latter had not lost weight during the river stay, as had all the salmon at stripping. The loss of weight in breeding fish from capture to stripping was investigated by Ahlbäck (1974) in River Skellefte. All salmon kept in special ponds for breeding were tagged individually and weighed at capture, before (and after) stripping and a few times during retention. From his material (52 females, 40 males) it is possible to calculate a regression for loss in weight (\%) against time (days). The relation is linear and the regression is about $0.1 \%$ loss in weight per day for both sexes ( $y=$ $0.6-0.1013 x ; r=0.4535, t_{r}=3.59$ ). The average time from recapture to stripping date was $79 \mathrm{~d}$ which corresponds to $8 \%$ weight loss. Applying the correction figures $(2.5 \%$ and $8 \%)$ to the mean weights of A.3+ (and A.2+ for River Lule in 1976, see above) tagged salmon in Fig. 9 brings them down to the level of the untagged fish. For the River Lule salmon (most data), the corrected weight of A.3 + tagged salmon is $0.6 \%$ lower than the average of untagged salmon (7.70 against $7.75 \mathrm{~kg}$ ) and of A.2+ in $19760.5 \%$ lower (4.10 against $4.12 \mathrm{~kg}$ ). The values from the other 2 river stocks are also well within the accuracy of weighing.
Considering also the selection of breeding fish and the possible, but in that case very small, effect of released unmarked fish below $13 \mathrm{~cm}$ length it seems safe to conclude that a possible impact of tags and tagging on the growth of Baltic salmon is so small that it can be regarded negligible. The results presented, based on tagging, thus appear to be representative for at least the part of Baltic salmon emanating from reared smolts (70\%, Anon., 1982).

\section{LITERATURE CITED}

Ahlbäck, G. (1974). Viktminskning hos lax under vistelsen i avelsbassäng (Swed). Laxforskningsinst. Inf. No 8

Allan, I., Ritter, J. (1977). Salmonid terminology. J. Cons. int. Explor. Mer 37 (3) : 293-299

Alm, G. (1934). Salmon in the Baltic precincts. Rapp. P.-v. Réun. Cons. int. Explor. Mer 92: 1-63

Alm, G. (1959). Connection between maturity, size and age in fishes. Rep. Inst. Freshwat. Res. Drottningholm 40: 5-145

Anon. (1980). Report of the Baltic Salmon Assessment Working Group. ICES, Doc. C. M. 1980/M: 3 (mimeo.)

Anon. (1982). Report of the Baltic Salmon Assessment Working Group. ICES, Doc. C. M. 1982/Assess. 20, p. 37

Anon. (1983). Rapport final 1980-1983 d'Action COST 46, Mariculture. Commission des Communautes Europeennes, Doc, XII/1199/82

Aro, E., Sjoblom, V. (1981). The abundance of cod in the seas around Finland in 1974-80. ICES, Doc. C. M. 1981/J: 20 (mimeo.)

Berg, L. S. (1948). Fresh water fishes of the Sovjet Union and adjacent countries. Part 1. Moscow, Leningrad. Translated from Russian by Israel Program for Scientific Translations Jerusalem 1962

Carlin, B. (1955a). Försök med märkning av odlade laxungar. (Swed.) Svenska Vattenkraftfören. publ. 451 (1955: 8): $87-104$

Carlin, B. (1955b). Tagging of salmon smolts in the river Lagan. Rep. Inst. Freshwat. Res. Drottningholm 36: 57-74

Carlin, B. (1959). Results of salmon smolt tagging in the Baltic area. Rapp. P.-v. Réun. Cons. int. Explor. Mer 147: 89-96

Carlin, B. (1960). Scales from salmon with known age. ICES, Doc. C. M. 1960, Salmon and trout committee

Carlin, B. (1963). Laxforskning med hålkort. (Swed.) IBMnytt, No. 2

Carlin, B. (1968). Salmon tagging experiments. Series of lectures. The Atlantic Salmon Association Montreal, Canada

Carlin, B. (1971). Data processing in Swedish salmon tagging experiments. Swedish Salmon Res. Inst. Rep. 3: 1-3

Chelkowski, Z., Chelkowska, B. (1979). Occurence of salmon (Salmo salar L.) in the Szczecin firth and lower Odra in 1976. Acta Ichtyol. et Piscat. 9 (2): 15-20

Christensen, O. (1961). Preliminary results of an investigation on the food of Baltic salmon. ICES, Doc. C. M. 1961/93 (mimeo.)

Christensen, O. (1976). Notes on catches of Baltic salmon 1971-75. ICES, Doc. C. M. 1976/M: 12 (mimeo.)

Christensen, O., Larsson, P.-O. (ed.) (1979). Review of Baltic salmon research. ICES Coop. Res. Rep. No. 89: 1-124

Chrzan, F. (1959). Losos i troć w polskich poławach na BaY tyku w latach 1945-1955 (Polish). Prace Morsk. Inst. Ryb. A-10: $273-340$

Chrzan, F. (1969). Biologiczna charakterystyka Yososia Salmo salar z rzeki Drawy oparta na badaniu Kusek (Polish). Prace Morsk. Inst. Ryb. A-15: 153-191 
Eichelbaum, E. (1916). Reife und Nahrung von eingesandten Lachsen. Rapp. P.-v. Réun. Cons. int. Explor Mer 23 (2): $1-116$

Hansen, L. P. (1981). Returns of Carlin-tagged, fin-clipped and unmarked wild smolts of Atlantic saimon. Salmosalar L from the river Imsa, SW Norway. ICES, Doc. C. M. 1981/ M: 6 (mimeo.)

Hansen, L. P. (1983). Salmon ranching in Norway. In: Eriksson C., Ferranti, M. P., Larsson, P.-O. (ed.) Proceedings of Workshop on Sea Ranching of Atlantic Salmon, Lisbon, October 1982. Commission of European Communities, Doc. XII/1023/82, p. 95-108

Henking, H. (1931). Untersuchungen an Salmoniden, Teil II. Rapp. P.-v. Réun. Cons. int. Explor Mer 73: 1-122

Hessle, C. (1949). Recent years' increase in the catches of cod in the Swedish fishery. Annls, biol. Copenhagen 4: $145-148$

Isaksson, A., Bergman, P. K. (1978). An evaluation of two tagging methods and survival rates of different age and treatment groups of hatchery reared Atlantic salmon smolts. J. agric. Res. Iceland 10 (2): 74-99

Järvi, T. H. (1938). Fluctuations in the Baltic stock of salmon, 1921-35. Rapp. P.-v. Réun Cons. int. Explor. Mer 105: $1-114$

Järvi, T. H. (1948). On the periodicity of Salmon reproduction in the northern Baltic area and its causes. Rapp. P.-v. Réun. Cons. int. Explor. Mer 119: 1-131

Järvi, T. H., Menzies, W. J. M. (1936). The interpretation of the zones on scales of salmon, sea trout and brown trout. Rapp. P.-v. Réun. Cons. int. Explor Mer 97: 1-63

Johansson, H. (1973). Fenklippning av laxsmalt i Ume älv 1970-1973 (Swed.). Proceedings of Salmon Rearing Conference, Visby 1973, Doc. No. 8: 1-13

Kändler, R., Lühmann, M. (1957). Uber den Lachsbestand und die Erträge des deutschen Lachsfanges in der südöstlichen Ostsee. Ber dt. wiss. Kommn Meeresforsch. 14 (3): 233-254

Larsson, P.-O. (1982). Effects of reduced fishing for feeding salmon in the Baltic on home water fisheries according to simulations with the Carlin-Larsson population model. ICES, Doc. C. M. 1982/M: 45 (mimeo)

Larsson, P.-O., Pickova, J. (1978). Egg size of salmon (Salmo salar L.) in correlation to female age and weight in three river stocks. Swedish Salmon Res. Inst. Rep. 2: 1-6

Larsson, P.-O., Larsson, H.-O., Eriksson, C. (1979). Oversiktlig bedömning av resultaten av märkningsförsok på olika stammar av lax (Salmo salar L.). English summary: Review of Swedish salmon (Salmo salar L.) stocks based on results of tagging experiments. Swedish Salmon Res. Inst. Rep. 5: $1-28$

Lindroth, A. (1961). Sea food of Baltic salmon smolt. ICES, Doc. C. M. 1961/7 (mimeo.)

Lindroth, A. (1964). Ostersjölaxens storlek (Swed.). Svensk Fisk. Tidskr $73(3 / 4)$ : 29-34

Lindroth, A. (1965). The Baltic salmon stock. Mitt. int. Verein. theor. angew. Limnol. 13: 163-192

Lindroth, A. (1972). Heritability estimates of growth in fish. Aquilo Ser Zool. 13: 77-80

Lindroth, A. (1977). The smolt migration in the River Morrumsan (Sweden) 1963-1966. ICES, Doc. C. M. 1977/M: 8 (mimeo.)

Melnikova, M. N. (1980). Sovremennoje sostojanie stada Nevskovo lososja Salmo salar (1.). In: Skarlato, O. A., Saposnikova, G. Ch., Bakstansky, E. L. (ed.) Lososevidnye Ryby, Sbornik nautjnych trudov (Russ.). Zool. inst. Akad. Nauk. SSSR, Leningrad, p. 101-105

Mitans, A. P. (1970). Feeding of Baltic salmon smolts in the river and sea. Vop. Ikthiol. 10 (1): 60
Naevdahl, G., Bjerk, Ø., Holm, M., Lerøy, R., Møller, D. (1979). Growth rate and age at sexual maturity of Atlantic salmon smoltifying aged one and two years. FiskDir. Skr Ser. Havunders. 17. 11-17

Olofsson, O. (1932). 1931, ett nytt smålaxår i övre Norrland (Swed.). Svensk Fisk. Tidskr 41. 125-130

Osterdahl, L. (1964). Smolt investigations in the River Rickleån. Swedish Salmon Res. Inst. Rep. 8: 1-7

Osterdahl, L. (1969). The smolt run of a small Swedish river In: Northcote, T (ed.) Salmon and trout in streams. H. R. McMillan lectures in fisheries. University of British Columbia, p. 205-215

Pippy, J. H. C., Reddin, D. G. (1982). Report on the 1981/82 international Atlantic satmon scale reading exercise. ICES, Doc. C. M. 1982/M: 4 (mimeo.)

Rasmuson, M. (1983). Population genetic aspects on salmon culture. Proceedings of Symposium on Salmon Problems, Luleå 1983 (MS)

Refstie, T (1979). Avlsarbeid på laks og aure (Norweg.). Proceedings of Salmon Rearing Conference, Storlien 1979, p. $40-48$

Ricker, W. E. (1976). Review of the rate of growth and mortality of Pacific salmon in salt water and non catch mortality caused by fishing. J. Fish. Res. Bd Can. 33: 1483-1524

Ritter, J. A., Marchall, T. L., Reddin, D. G. (1979). A review of non-catch fishing mortality as it relates to Atlantic salmon (Salmo salar) fisheries. ICES, Doc. C. M. 1979/M: 25 (mimeo.)

Ryman, N. (1972). An analysis of growth capability in full sib families of salmon (Salmo salar L.). Heriditas 70: 119-127

Sandström, O., Sörlin, T (1981). Production ecology in the northern Baltic. Hydrobiologia 76 (1-2): 87-96

Saunders, R. L., Allen, K. R. (1967). Effects of tagging and of finclipping on the survival and growth of Atlantic salmon between smolt and adult stages. J. Fish. Res. Bd Can. 24 : $2595-2611$

Svärdson, G. (1955). Salmon stock fluctuations in the Baltic Sea. Rep. Inst. Freshwat. Res. Drottningholm 36: 226-262

Svärdson, G. (1957). Laxen och klimatet (English summary Salmon and the climate). Rep. Inst. Freshwat. Res. Drottningholm 38: 357-384

Thorpe, J. E., Morgan, R. I. G. (1978). Parental influence on growth rate, smolting rate and survival in hatchery reared juvenile Atlantic salmon, Salmo salar. J. Fish Biol. 13 $549-556$

Thorpe, J. E., Morgan, R. I. G. (1980). Growth-rate and srnolting-rate of progeny of male Atlantic salmon parr, Salmo salar L. J. Fish Biol. 17: 451-459

Thurow, F. (1964). Die Selektionswirkung von Angelhaken in der Lachstreibleinenfischerei Arch. FischWiss. 15 (2) 130-137

Thurow, F. (1966). Beiträge zur Biologie und Bestandkunde des Allantischen Lachses (Salmo salar L.) in der Ostsee. Ber dt. wiss. Kommn Meeresforsch. 18 (3/4): 223-379

Thurow, F. (1968). On food, behaviour and population mechanism of Baltic salmon. Swedish Salmon Res. Inst. Rep. 4: 1-16

Thurow, F. (1969). Investigations on the sea lite of Baltic salmon in 1968. Annls. biol. Copenhagen 25: 235-236

Thurow, F (1972). A tentative approach to offshore yield assessment in Baltic salmon. ICES, Doc. C. M. 1972/M: 5 (mimeo.)

Thurow, F. (1973). Growth parameters of Baltic salmon (Salmo salar L.). Ber dt. wiss. Kommn Meeresforsch. 22 (4) : 445-451

Toivonen, J (1977). Difference in recaptures of wild and hatchery-reared salmon smolts. ICES, Doc. C. M. 1977/M: 7 (mimeo.) 